\title{
UPAYA PELAKSANAAN SUPERVISI KELOMPOK UNTUK GURU DALAM MENGEMBANGKAN EVALUASI PEMBELAJARAN SISWA DI SD NEGERI 10 SURO MUNCAR KECAMATAN UJAN MAS SEMESTER I (SATU) TAHUN PELAJARAN 2014/2015
}

\author{
Darwis
}

\begin{abstract}
Abstrak
Penelitian ini merupakan penelitian tindakan sekolah, yang dilaksanakan untuk memperbaiki kompetensi guru dalam mengembangkan perangkat evaluasi pembelajaran. Penelitian dilaksanakan di SD Negeri 10 Kecamatan Ujan Mas, pada semester I tahun pelajaran 2014/2015. Pendekatan penelitian adalah pendekatan kualitatif, yaitu menguraikan fakta dan hubungan antar fakta penelitian secara tekstual sehingga mudah dipahami pembaca secara umum. Berdasarkan atas hasil penelitian tindakan sekolah yang dilakukan, dapat dibuat kesimpulan sebagai berikut: (1) Pelaksanaan supervisi dengan teknik kelompok untuk meningkatkan kemampuan guru mengembangkan evaluasi pembelajaran dilakukan dengan tiga tahapan utama, yaitu tahapan (a) Penanaman konsep evaluasi pembelajaran dan indikator pengukuran kualitas evaluasi pembelajaran. Hal ini diselenggarakan pada pertemuan pra observasi; (b) Pelatihan dan pengukuran evaluasi pembelajaran. Hal ini diselenggarakan pada pertemuan observasi; (c) Evaluasi dan problem solving permasalahan dalam pengembangan evaluasi pembelajaran guru; (2) Terjadi peningkatan kemampuan guru mengembangkan perangkat evaluasi pembelajaran yang sesuai dengan konsep-konsep di dunia kependidikan.
\end{abstract}

Kata Kunci : Supervisi kelompok, hasil belajar siswa.

\section{PENDAHULUAN}

Pembelajaran merupakan inti dan muara dari segenap proses pengelolaan pendidikan. Kualitas sebuah lembaga pendidikan hakikatnya diukur dari kualitas proses pembelajarannya, disamping output dan outcome yang dihasilkan. Oleh karena itu kriteria mutu dan keberhasilan pembelajaran seharusnya dibuat secara rinci, sehingga benar-benar measurable and observable (dapat diukur dan diamati).

Namun kenyataannya, membuat kriteria dan indikator keberhasilan pembelajaran tidaklah semudah mengukur produktivitas dan kualitas pada bidang pekerjaan lain. Pembelajaran melibatkan unsur siswa dengan segala karakteristiknya, mulai dari latar belakang keluarga, lingkungan, ekonomi, kemampan, motivasi, dan sebagainya. Selain itu perubahan yang terjadi pada diri siswa setelah melalui sebuah proses pembelajaran juga tidak nampak dan sulit diukur, terutama pada dimensi nilai dan sikap (Depdiknas, 2008).

Kejelasan kriteria dan indikator keberhasilan pembelajaran bukan saja akan memperjelas target dalam setiap tahapan pembelajaran, namun sekaligus juga meningkatkan accountability guru. Idealnya, setiap guru memiliki kemampuan menyusun kriteria dan indikator keberhasilan pembelajaran sesuai dengan bidang tugas masing-masing (Depdiknas, 2008). Indikator-indikator tersebut harus masuk dalam perangkat evaluasi belajar, sehingga pengukuran keberhasilan proses pembelajaran yang dilakukan melalui evaluasi belajar benar-benar mendekati kondisi riil hasil belajar siswa dalam aspek yang luas yang mampu 
menggambarkan keberhasil proses pembelajaran yang dikembangkan guru.

Evaluasi menurut Kumano (2001) merupakan penilaian terhadap data yang dikumpulkan melalui kegiatan asesmen. Penilaian (assessment) adalah penerapan berbagai cara dan penggunaan beragam alat penilaian untuk memperoleh informasi tentang sejauh mana hasil belajar peserta didik atau ketercapaian kompetensi (rangkaian kemampuan) peserta didik.

Penilaian menjawab pertanyaan tentang sebaik apa hasil atau prestasi belajar seorang peserta didik. Hasil penilaian dapat berupa nilai kualitatif (pernyataan naratif dalam kata-kata) dan nilai kuantitatif (berupa angka). Pengukuran berhubungan dengan proses pencarian atau penentuan nilai kuantitatif tersebut. Penilaian hasil belajar pada dasarnya adalah mempermasalahkan, bagaimana pengajar (guru) dapat mengetahui hasil pembelajaran yang telah dilakukan. Pengajar harus mengetahui sejauh mana pebelajar (learner) telah mengerti bahan yang telah diajarkan atau sejauh mana tujuan/kompetensi dari kegiatan pembelajaran yang dikelola dapat dicapai. Tingkat pencapaian kompetensi atau tujuan instruksional dari kegiatan pembelajaran yang telah dilaksanakan itu dapat dinyatakan dengan nilai. Evaluasi mencakup dua kegiatan pengukuran dan penilaian. Evaluasi adalah kegiatan atau proses untuk menilai sesuatu, untuk dapat menentukan nilai dari sesuatu yang sedang dinilai, dilakukan pengukuran, dan wujud dari pengukuran itu adalah pengujian. Dapat dikatakan bahwa evaluasi merupakan penetapan nilai atau implikasi dari hasil penilaian.

Dalam mengembangkan evaluasi pembelajaran, menurut Danim (2007), mutu pendidikan dilihat dari tiga perspektif yaitu masukan, proses, dan output. Evaluasi pembelajaran paling tidak harus dilihat dengan menggunakan tiga perspektif tersebut. Evaluasi masukan pembelajaran menekankan pada penilaian karakteristik peserta didik, keadaan dan kelengkapan sarana prasarana pembelajaran, strategi pembelajaran yang sesuai, serta keadaan lingkungan pembelajaran. Evaluasi proses pembelajaran menekankan pada penialain pengelolaan pembelajaran yang dilaksanakan oleh guru meliputi kinerja guru, keefektifan media pembelajaran, iklim kelas, serta keadaan lingkungan pembelajaran. Evaluasi hasil pembelajaran merupakan pengukuran hasil belajar siswa baik menggunakan test maupun non test.

Sebagai salah satu dari fungsi manajemen, pengertian supervisi telah berkembang secara khusus. Secara umum yang dimaksud dengan supervisi adalah melakukan pengamatan secara langsung dan berkala oleh atasan terhadap pekerjaan yang dilaksanakan oleh bawahan untuk kemudian apabila ditemukan masalah, segera diberikan petunjuk atau bantuan yang bersifat langsung guna Manfaat dan Tujuan Supervisi.

Apabila supervisi dapat dilakukan dengan baik, akan diperoleh banyak manfaat. Manfaat tersebut diantaranya adalah sebagai berikut (Suarli dan Bachtiar, 2009): Supervisi untuk meningkatkan afektifitas dan efisien kerja. Sesuai dengan tujuannya supervise untuk membantu guru dalam meningkatkan pembelajaran, sehingga pada akhirnya dapat meningkatkan belajar siswa, maka istilah yang sering digunakan adalah supervisi pengajaran (instructional supervision) (Depdiknas, 2008). Menurut Gwyn, teknik-teknik supervisi itu bisa dikelompokkan menjadi dua kelompok, yaitu. teknik supervisi individual, danteknik supervisi kelompok (Depdiknas, 2008).

\section{METODE}

Penelitian ini adalah penelitian tindakan sekolah, yaitu penelitian yang dilaksanakan oleh peneliti (umumnya juga praktisi) di sekolah untuk membuat peneliti lebih profesional terhadap pekerjaannya, memperbaiki praktikpraktik kerja, dan melakukan inovasi sekolah serta mengembangkan ilmu pengetahuan terapan. Praktik-praktik kerja yang diperbaiki dalam penelitian ini adalah praktik pengembangan evaluasi pembelajaran oleh guru melalui perbaikan program supervisi. 
Pendekatan yang digunakan dalam penelitian ini adalah pendekatan kualitatif yaitu pendekatan dimana keterkaitan antar fakta dalam peneitian diuraikan secara tekstual sehingga mudah dipahami pembaca.

Penelitian dilaksanakan di SD Negeri 10 Ujan Mas. Alasan pemilihan lokasi penelitian adalah (a) Kondisi dibutuhkannya pemberian supervisi dengan segera agar kompetensi guru dalam mengembangkan evaluasi pembelajaran dapat ditingkatkan; (b) Kemudahan pengambilan data di lokasi penelitian. Teknik pengumpulan data: (1) dokumentasi yaitu dokumen kegiatan guru dalam mengembangkan evaluasi pembelajaran, profil sekolah, dokumen perencanaan, pelaksanaan dan refleksi pada kegiatan supervisi kelompok, dan dokumen lainnya yang relevan; (2) observasi dilakukan terkait dengan teknik-teknik supervisi kelompok, perbaikan yang dilakukan dalam supervisi kelompok, respon guru dalam mengikuti program supervisi kelompok, dan kemampuan guru dalam mengembangkan evaluasi pembelajaran; (3) wawancara dilakukan kepada guru dan tim observator untuk melengkapi data-data yang ditemukan dalam kegiatan observasi dan dokumentasi guna mengurai kejelasan atas faktafakta yang ditemukan.

Prosedur Penelitian mencakup:

Perencanaan tindakan (planning), Perencanaan tindakan merupakan kegiatan mempersiapkan segala sesuatu yang berkaitan dengan kegiatan penelitian, mulai dari pelaksanaan observasi, menyusun lembar observasi kepala sekolah, menyusun format catatan kejadian, menyusun format kegiatan refleksi, serta menyusun alat-alat pengukuran kemampuan guru mengembangkan evaluasi pembelajaran siswa; (2) Pelaksanaan tindakan (action), perencanaan tindakan yang telah disusun dilaksanakan oleh kepala sekolah terhadap subyek penelitian yanitu para guru di SDN 10 Ujan Mas; (3) Pengamatan tindakan (observasi), pengamatan dilaksanakan oleh peneliti dan tim observasi, terkait dengan perilaku para guru dalam mengikuti program supervisi, hasil pelaksanaan supervisi, dan kondisi-kondisi lain yang dapat menjadi data penelitian; (4) Refleksi, hasil observasi selanjutnya dijadikan bahan pertimbangan untuk dilakukannya perbaikan-pernaikan. Refleksi merupakan perumusan langkah-langkah tindak lanjut yang perlu dilakukan berdasarkan hasil observasi.

\section{HASIL}

\section{Kemampuan Guru Mengembangkan Evaluasi pembelajaran Pra Penelitian}

Kemampuan guru mengembangkan evaluasi pembelajaran selama ini hanya dilakukan dengan berdasarkan pada penilaian atas hasil belajar siswa. Guru masih kurang memperhatikan evaluasi masukan pembelajaran dan evaluasi proses pembelajaran. Dengan demikian, keberhasilan proses pembelajaran dinilai dengan mengabaikan bagaimana input dan proses pembelajaran dikembangkan, sehingga kegagalan yang terjadi dianggap hanya bersumber dari kurangnya kecakapan awal siswa. Hal ini mengakibatkan guru kurang mempehatikan proses pembelajaran, input seperti sarana dan prasarana pembelajaran.

Kondisi masih kurangnya kemampuan guru dalam mengembangkan evaluasi pembelajaran, berdasarkan hasil pengamatan pada 11 guru di SD N 10 Ujan Mas dapat dilihat pada hasil tentang "perhatian terhadap obyek evaluasi pembelajaran' degan rata-rata kemampuan guru $=2,6$. Hasil pengamatan atas pelaksanaan pembimbingan pada guru untuk mengembangkan kemampuan memotivasi belajar siswa adalah sebagai berikut: (1) terdapat guru yang mengalami kesulitan mengembangkan evaluasi pembelajaran yang sesuai dengan indikator-indikator kelengkapan evaluasi; (2) terdapat guru yang bersifat individual, kurang berperan dalam aktivitas kelompok.

Adapun hasil observasi terhadap kemampuan rata-rata seluruh guru dalam hal "kemampuan guru mengembangkan evaluasi pembelajaran" pada siklus I dengan nilai Ratarata kemampuan guru $=3,6$. Hasil observasi 
terhadap kemampuan guru mengembangkan evaluasi pembelajaran Siklus II adalah dengan nilai rata-rata 4,3. Hasil tersebut menunjukkan terjadinya peningkatan kemampuan guru pada siklus II, dimana skor rata-rata kemampuan guru telah mecapi 4,3. Dengan kata lain, kemampuan guru berada dalam tingkatan tinggi dan mengarah pada tingkatan sangat tinggi.

Hasil observasi menunjukkan telah baiknya pelaksnakaan supervisi kelompok untuk meningkatkan kemampuan guru dalam mengembangkan perangkat evaluasi pembelajaran yang sesuai dengan konsep-konsep yang dikemukakan para ahli kependidikan. Sedangkan kendala yang masih dirasakan hanya sekedar adanya guru yang masih kurang nyaman dengan model evaluasi pembelajaran yang dikembangkan karena terbiasa dengan kebiasaan lama yang lebih mudah.

\section{PEMBAHASAN}

Kegiatan supervisi kelompok dalam penelitian ini dilaksanakan untuk meningkatkan kemampuan guru mengembangkan perangkat evaluasi pembelajaran yang baik berdasarkan konsep-konsep eavluasi pembelajaran dalam kependidikan. Melalui supervisi kelompok, diupayakan bahwa perangkat evaluasi harus memasukkan obyek-obyek evaluasi secara lengkap yang mencakup evaluasi masukan, evaluasi proses pembelajaran, dan evaluasi hasil pembelajaran secara langkap. Pengembangan juga dilakukan dalam evaluasi hasil yang selama ini masih dikembangkan secara tidak lengkap oleh guru. Dalam penelitian ini, evaluasi hasil pembelajaran dilakukan dengan marinci aspek kognitif, psikomotorik, dan afektif secara tepat.

Supervisi dilakukan bukan hanya dengan memberikan konsep-konsep semata, akan tetapi dilaksanakan dengan melibatkan pelatihan dan problem solving atas permasalahan yang dialami guru dalam mengembangkan perangkat evaluasi pembelajaran. Permasalahan-permasalahan yang dialami guru dipecahkan satu per satu dalam ruangan pembimbingan, sehingga pada akhir siklus II sudah tidak terdapat guru yang mengalami kesulitan.

Hasil penelitian menunjukkan terjadinya peningkatan kemampuan guru dari pra pelaksanaan penelitian $(2,6)$, Siklus I $(3,6)$, dan pada siklus II mencapai skor rerata $(4,3)$. Hasil tersebut dapat digambarkan dengan grafik berikut:

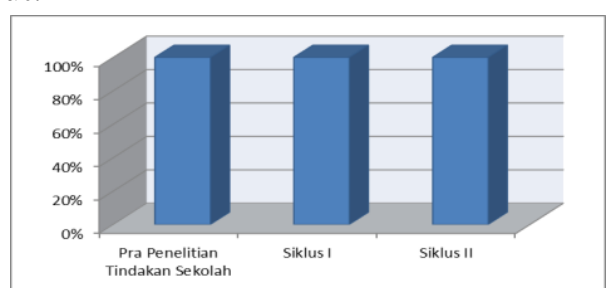

Gambar 4.1. Peningkatan motivasi kerja guru.

Berdasarkan gambar tersebut, terlihat bahwa pada siklus I terjadi peningkatan kemampuan guru yang sangat tinggi, yang ditunjukkan dengan garis yang curam. Peningkatan kemampuan guru dalam mengembangkan perangkat evaluasi masih dapat ditingkatkan lagi pada siklus II, yang hal ini ditunjukkan dengan masih naiknya garis kemampuan guru pada siklus II.

Peningkatan kemampuan guru tersebut menunjukkan kesesuaian hasil pelaksanaan supervisi dengan konsep supervisi yang ada di dunia pendidikan, dimana supervisi memiliki peran membantu guru dalam meningkatkan kualitas penyelenggaraan segenap proses pembelajaran, termasuk dalam mengembangkan perangkat pembelajaran, sebagaimana kemampuan guru yang dikategorikan dalam kompetensi akademis.

Pelaksanaan supervisi dalam penelitian ini dikembangkan melalui tahapan yang lengkap, yaitu tahapan pemberian konsep, tahap observasi dan pelatihan, serta tahap evaluasi serta problem solving. Guru secara langsung terlibat dalam kegiatan observasi atas hasil kerjanya menyusun perangkat evaluasi pembelajaran, sehingga guru mampu memahami dimana letak kelemahannya yang perlu diperbaiki. Pemberian pengalaman pada guru bukan hanya sebatas bagaimana cara mengembangkan perangkat evaluasi 
pembelajaran yang baku, akan tetapi juga pemberian pengalaman bagaimana mengukur perangkat evaluasi berdasarkan standar-standar yang baku.

\section{SIMPULAN}

Berdasarkan atas hasil penelitian tindakan sekolah yang dilakukan, dapat disimpulkan bahwa pelaksanaan supervisi dengan teknik kelompok untuk meningkatkan kemampuan guru mengembangkan evaluasi pembelajaran dilakukan dengan tiga tahapan utama, yaitu tahapan (a) Penanaman konsep evaluasi pembelajaran dan indikator pengukuran kualitas evaluasi pembelajaran. Hal ini diselenggarakan pada pertemuan pra observasi; (b) Pelatihan dan pengukuran evaluasi pembelajaran. Hal ini diselenggarakan pada pertemuan observasi; (c) Evaluasi dan problem solving permasalahan dalam pengembangan evaluasi pembelajaran guru. Hasil pengamatan menunjukkan terjadi peningkatan kemampuan guru mengembangkan perangkat evaluasi pembelajaran yang sesuai dengan konsep-konsep di dunia kependidikan.

\section{SARAN}

Berdasarkan atas hasil penelitian, saransaran yang diajukan adalah sebagai berikut: (1) pelaksanaan supervisi keompok perlu diselenggarakan untuk meningkatkan kompetensi lainnya pada guru, sehingga kualitas penyelenggaraan pendidikan di sekolah dapat diperbaiki melalui supervisi; (2) supervisor perlu meningkatkan kepekaannya dalam mengidentifikasi malasalah guru, sehingga daya permasalahan-permasalahan guru secara bertahap dapat diperbaiki.

\section{DAFTAR PUSTAKA}

Arikunto, S \& Jabar. 2004. Evaluasi Program Pendidikan. Jakarta: Bumi Aksara

Budiyono. 2007. Motede Statistik untuk Penelitian. Surakarta: Universitas Sebelas Maret
Calongesi, J.S. 1995. Merancang Tes untuk Menilai Prestasi Siswa. Bandung : ITB

Danim, Sudarwan. 2002. Inovasi Pendidikan. Bandung: Pustaka Setia.

Danim, Sudarwan. 2010. Kepemimpinan Pendidikan. Bandung: Alfabeta

Depdiknas. 2001. Kurikulum Sekolah Dasar. Jakarta: Depdiknas.

Dediknas. 2003. Undang-Undang R I Nomor 20 Tentang Sistem Pendidikan Nasional. Bandung: Citra Umbara.

Depdiknas. 2004. Pola Pembinaan Sistem Pendidikan Tenaga Kependidikan PGSD. Jakarta: Depdiknas.

Depdiknas. 2005. Undang-Undang RI Nomor 14 Tentang Guru Dan Dosen. Jakarta: Depdiknas.

Depdiknas. 2006. Standar Kompetensi Guru Kelas SD/MI Lulusan S 1 PGSD. Jakarta: Depdiknas.

Depdiknas.2008. StanPembangunan Pendidkan Nasional. Jakarta: Depdiknas.

Hasan, S.H. 2004. Kurikulum dan Tujuan Pendidikan. Bandung: Pasca Sarjana UPI.

Komarudin. 2004. Manajemen Pengawasan Kualitas Terpadu. Jakarta: Rajawali,

Ngalim Purwanto. 2009. Administrasi dan Supervisi Pendidikan. Bandung: Remaja Rosdakarya

Puslitjaknov, 2008. Metode Penelitian Pengembangan. Jakarta: Depdiknas

Suharsimi Arikunto. 1997. Prosedur Penelitian. Jakarta: Rineka 